\title{
Study of Resistance to 82 Clinical Cases Enterobacteriaceae to Beta-lactam Antibiotics
}

\author{
Mahnaz Milani ${ }^{1}$ \\ ${ }^{1}$ Department of Microbiology, Shahid Beheshti University, Tehran, Iran \\ Correspondence: Mahnaz Milani, Department of Microbiology, Shahid Beheshti University, Tehran, Iran. \\ mail: mahnazmilani@yahoo.com \\ Received: August 7, 2016 \\ Accepted: August 26, 2016 \\ Online Published: November 1, 2016 \\ doi:10.5539/jmbr.v6n1p93 \\ URL: http://dx.doi.org/10.5539/jmbr.v6n1p93
}

\begin{abstract}
Knowledge of antimicrobial resistance patterns in $E$. coli, the predominant pathogen associated with urinary tract infections (UTI) is important as a guide in selecting empirical antimicrobial therapy. To describe the antimicrobial susceptibility of $E$. coli associated with UTI in a major university hospital in Tehran (Iran), seventy-six clinical isolates of $E$. coli were studied for susceptibility to $\beta$-lactam antibiotics by the disc diffusion method and Minimal Inhibitory Concentrations determination. All isolates were resistant to ampicillin, amoxicillin and oxacillin. Resistance to the other tested antibiotics was shown to be $93.4 \%$ to cefradine, $76.3 \%$ to carbenicillin, $47.3 \%$ to cefazoline, $50 \%$ to cefalexin and $32.8 \%$ to cephalothin while $1.3 \%$ expressed resistance to cefoxitime, and $2.6 \%$ were resistant to ceftizoxime and ceftriaxone. Substrate hydrolysis by ultra violet spectroscopy showed that $87.4 \%$ harbored penicillinases, 9\% produced cephlosporinases and 3.6\% degraded both substrates. Clavulanic acid inhibited enzyme activity in $82.9 \%$, of which $78.95 \%$ was penicillinases (group IIa) and $3.95 \%$ was cephalosporinases (group IIb) of the Bush classification system. These results indicate that $E$. coli can posses a variety of $\beta$-lactamases that are responsible for $\beta$-lactam resistance. Members of the family Enterobacteriaceae, particularly Escherichia coli is the most common causes of urinary tract infections in hospitals and societies. Betalactam antibiotics, particularly the third and fourth generation of cephalosporins are effective in treating these infections.
\end{abstract}

Keywords: Beta-lactams, Enterobacteriaceae, Escherichia coli

\section{Introduction}

Urinary Tract Infections (UTI) are the second most common infections present in community practice (Gonzalez \& Schaeffer, 1999). Members of Enterobacteriaceae, specifically, E. coli are the main causes of urinary infections (Gupta, 2003). Extensive use of $\beta$-lactams in veterinary medicine and human practice is believed to be associated with selection of resistance in both pathogenic and nonpathogenic isolates of $E$. coli (Livermore, 1995). More than two hundred $\beta$ lactamase enzymes are recognized which are classified into 4 main groups and 8 subgroups (Bush \& Jacoby, 1996; Bush, 1989). The resistance of Enterobacter spp. to $\beta$-lactam antibiotics is most frequently mediated by production of TEM, SHV and AmpC $\beta$-lactamase (Barnaud et al., 2001). In the last decade, production of plasmidmediated ESBL which hydrolyzes a wide range of the most recently developed cephalosporins, has been recognized as an additional important emerging mechanism of resistance among members of the family Enterobacteriaceae including clinical isolates of E. coli (Bradford, 2001; Pitout et al., 1998). The first plasmid mediated Blactamases (TEM-1) was described in E. coli in 1960 and within a few years, it was found in many different genera of Gram-negative bacteria (Bradford, 2001). The AmpC family of $\beta$-lactamases occurs both chromosomally and plasmid-mediated in E. coli and plasmid encoded AmpC $\beta$-lactamases are found to be responsible for global outbreaks (Cudron, Moland, \& Sanders, 1997; Eftekhar, 2005). We studied 76 urinary isolates of $E$. coli for their susceptibility to $12 \beta$-lactam antibiotics. Preferred substrate hydrolysis was performed to determine the class of $\beta$-lactamases. DNA amplification of $\beta$ lactamase types TEM, SHV and AmpC genes was carried out by PCR using type specific primers of blaTEM, ampC and SHV genes for all of the isolates.

\section{Materials and Methods}

Bacteria. Seventy-six clinical isolates of E. coli were selected from a collection of urinary Enterobacteriaceae from the Bacteriology Laboratory of Vali-E-Asr Hospital in Tehran (Iran) (Hosseini-Mazinani, Jafar-Nejad, \& Ghandili, 2003). E. coli ATCC 25922 was used as a control for antibiotic susceptibility tests. K. pneumoniae 57-1 carrying 
plasmid mediated SHV gene, E. coli MK148 carrying the ampC gene and E. coli harboring pTEM were used as positive controls for DNA amplification by PCR (Hosseini-Mazinani, 2996). Antibiotic susceptibility. The antibiotic susceptibility of bacteria was initially carried out by the disc diffusion method according to the NCCLS recommendations (National Committee for Clinical Laboratory Standards [NCCLS], 2000). The antibiotic discs were ampicillin $(10 \mu \mathrm{g})$, amoxicillin $(25 \mu \mathrm{g})$, carbenicillin $(100 \mu \mathrm{g})$, cefalexin $(30 \mu \mathrm{g})$, cephalothin $(30 \mu \mathrm{g})$, cefazoline $(30 \mu \mathrm{g})$, cefradine $(30 \mu \mathrm{g})$, oxacillin $(1 \mu \mathrm{g})$, ceftazidime $(30 \mu \mathrm{g})$, ceftriaxone $(30 \mu \mathrm{g})$, ceftizoxime $(30$ $\mu \mathrm{g})$ (Padtan Teb, Tehran, Iran) and amoxicillin-clavulonic acid (20/10 $\mu \mathrm{g}$, Difco, USA). Minimum Inhibitory Concentrations (MIC) of the isolates was determined for ampicillin, ceftazidime, cefotaxime, ceftriaxone, cefepime and imipenem by the microdilution broth method using the NCCLS standard procedure ([NCCLS], 2000). Screening for ESBL production. The double disc synergy test was used to screen for ESBL production (Gonzalez and Schaeffer, 1999). Cefotaxime (30 $\mu \mathrm{g})$, ceftriaxone (30 $\mu \mathrm{g})$ and ceftizoxime (30 $\mu \mathrm{g})$ were placed on Mueller Hinton agar plates adjacent to amoxicillin-clavulanic acid discs $(20 / 10 \mu \mathrm{g})$. ESBL production was inferred when cephalosporin inhibition zones expanded by the clavulanate.

Substrate hydrolysis. Relative hydrolysis rates of benzylpenicillin and cephaloridine were evaluated by UV spectroscopy. $\beta$-lactamase activity was determined by measuring the decrease in optical density of a $0.1 \mathrm{mM}$ solution of cephaloridine $(255 \mathrm{~nm})$ or benzylpenicillin $(240 \mathrm{~nm})$. Enzymes were called penicillinase if the relative rate of benzylpenicillin hydrolysis was approximately $30 \%$ higher than that of observed for cephaloridine, or cephalosporinase if cephaloridine was hydrolyzed at least $30 \%$ faster than penicillin (Livermore, 1995 ; Ross \& O'Callaghan, 1975).

DNA amplification. Plasmid DNA extraction was carried out using a rapid alkaline lysis method (Winokur, 2001). The oligonucleotide primers used for the PCR assays were; 5'-ATAAAATTCTTGAAGACGAAA3' and 5'GTCAGTTACCAATGCTTAATC-3' for TEM, 5'-TGGTTATGCGTTATATTCGCC-3' and 5'GGTTAGCGTTGCCAGTGCT-3' for SHV and 5'ATGCAACAACGACAATCCATC-3' and 5'GTTGGGGTAGTTGCGATTGG-3' for AmpC plactamases (Sutcliffe,1978 ; Bret, 1998). blaTEM and SHV primers were synthesized at the National Research Center for Genetic Engineering and Biotechnology, Iran and ampC primer was synthesized at Faza Pajooh (Tehran, Iran). Reactions were carried out in a Techne DNA thermocycler (Germany) in $25 \mu \mathrm{l}$ mixtures containing $10 \mathrm{mM}$ Tris- $\mathrm{HCl}$ (pH 8.3), $1 \mathrm{mM}$ EDTA, $1.5 \mathrm{mM} \mathrm{MgCl}$, $200 \mu \mathrm{M}$ of each deoxyribonucleoside triphosphate, $2-10 \mathrm{pM}$ of oligonucleotide primers and $1 \mathrm{u}$ of Taq DNA polymerase (Fermentas, Lithuania). Following a $4 \mathrm{~min}$ incubation time at $94^{\circ} \mathrm{C}, 35$ cycles were run with the following temperature profile for each cycle: $94^{\circ} \mathrm{C}$ for $1 \mathrm{~min}$, the proper annealing temperature for each primer $\left(58^{\circ} \mathrm{C}\right.$ for blaTEM, $59^{\circ} \mathrm{C}$ for ampC and $520 \mathrm{C}$ for SHV) for $1 \mathrm{~min}$ and $72^{\circ} \mathrm{C}$ for $1 \mathrm{~min}$. An additional 5-10 min incubation time was also carried out at $72^{\circ} \mathrm{C}$. PCR experiments for amplification of the SHV gene failed to produce a single DNA product regardless of numerous standardization strategies. Therefore, presence or absence of the desired fragment was determined on the basis of comparing the resulting bands with a positive control as well as DNA size markers.

\section{Findings}

\subsection{Detection and Identification of Bacteria}

Identifying bacteria by biochemical version and was confirmed by API $20 \mathrm{E}$ test.

The results showed that among 82 cases of Escherichia coli cases, 76 cases were Citrobacter freundii, a case was Enterobacter, a case was Klebsiella pneumoniae, a case was Klebsiella oxytoca, and a case was Hafnia.

\subsubsection{Antibiotic Susceptibility Results}

A) by disk diffusion method:

All tested bacteria were resistant to antibiotics like amoxicillin, ampicillin and Oxacillin and only $9 \%$ of cases were resistant to coamoxiclave. As it is shown in Figure 1 and Figure 2, resistance to Cefradine and carbenicillin was $97.5 \%$ and $79.20 \%$; and resistance to other antibiotics was $20.7 \%$ Cephalothin, $26.8 \%$ cefalexin and $31.7 \%$ cefazoline, $1.2 \%$ to Cefoxitime, $1.2 \%$ Ceftizoxime $1.2 \%$, and Ceftiaxime.

B) The method MIC:

The results of the MIC are shown in Figure 3. MIC test showed susceptibility to the samples. 


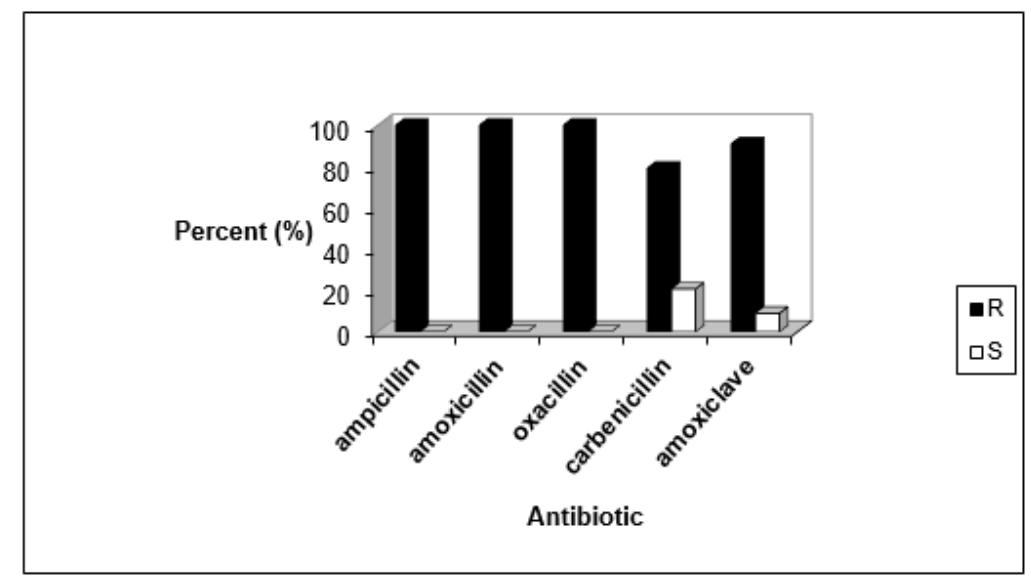

Figure 1. Results of Penicillin antibiotics

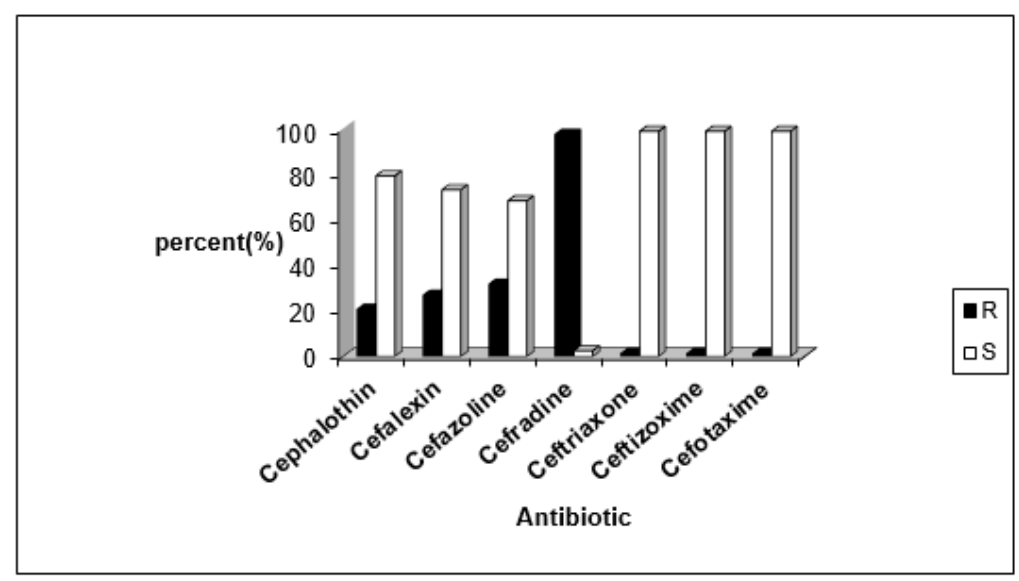

Figure 2. Results of Cephalosporin antibiotics

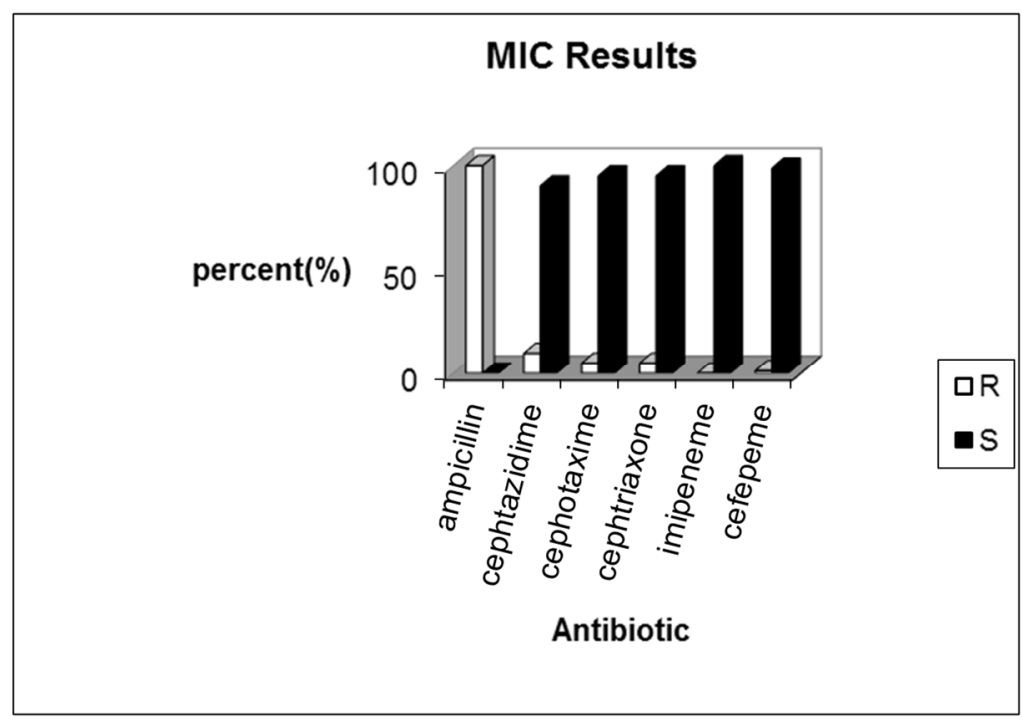

Figure 3. The results of the MIC 


\subsubsection{Results of colonies Test with iodometer}

Iodometer test showed the presence of enzyme in all bacteria.

As it is seen in Figure 4, colonies of bacteria with beta-lactamase enzyme have a white halo.

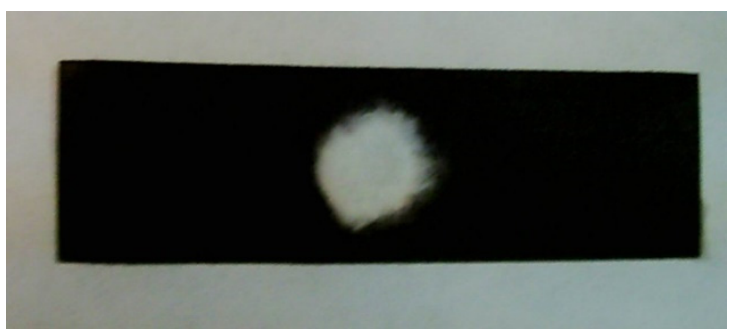

A

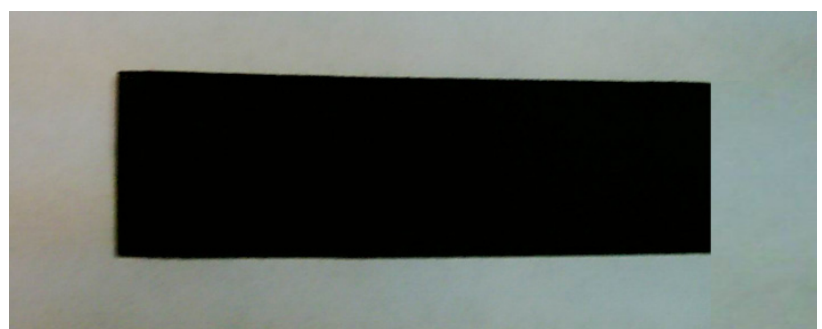

B

Figure 4. The results of the colony by Iodometer. A) Bacteria containing beta-lactamase B) bacteria lacking the enzyme beta-lactamase

\subsubsection{The Results of Substrate Hydrolysis}

As it is shown in Figure 5, depending on the rate of hydrolysis of benzyl penicillin and Cefaloridine to each other (spectrophotometry) $87.4 \%$ organisms contain enzyme penicillinase, $9 \%$ organisms contain enzymes Cephalosprinase and 3.6 percent contain both enzymes equally.

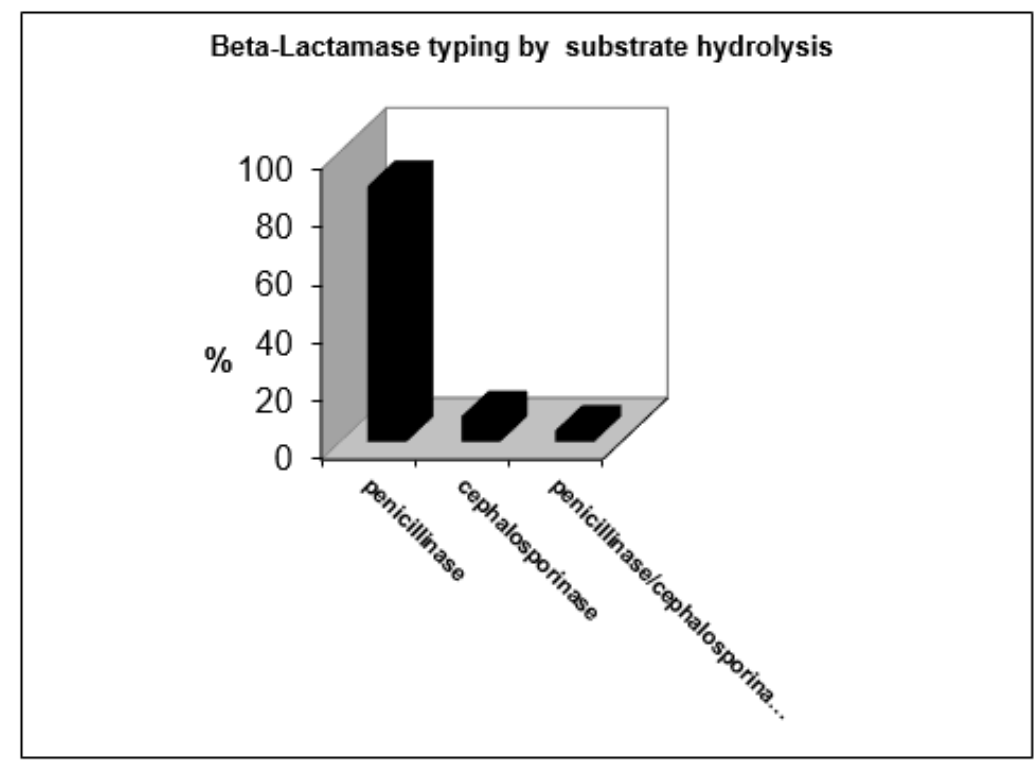

Figure 5. The results of hydrolysis of the substrate by Spectrophotometer

\subsubsection{Lactamase Classification Results}

None of the beta-lactamase enzymes tested showed no inhibition with EDTA. This does not mean that Group III was among the beta-lactamase. However, $91 \%$ enzymes were inhibited by clavulanic acid, and taking into account the results of hydrolysis of the substrate (Figure 5) showed that $87.4 \%$ organisms were penicillinase that were resistant to clavulanic acid, and this class of beta-lactamase belonged to Group 2a, 3.6\% organisms equally showed penicillinase and cephalosporinase and can be inhibited by clavulanic acid and belonged to the Group $2 b$, and $9 \%$ were penicillinase that cannot be inhibited by clavulanic acid which belonged to Group 4. Among the studied organisms, Group I, i.e. cephalosporinases were not resistant to clavulanic acid (Figure 6). 


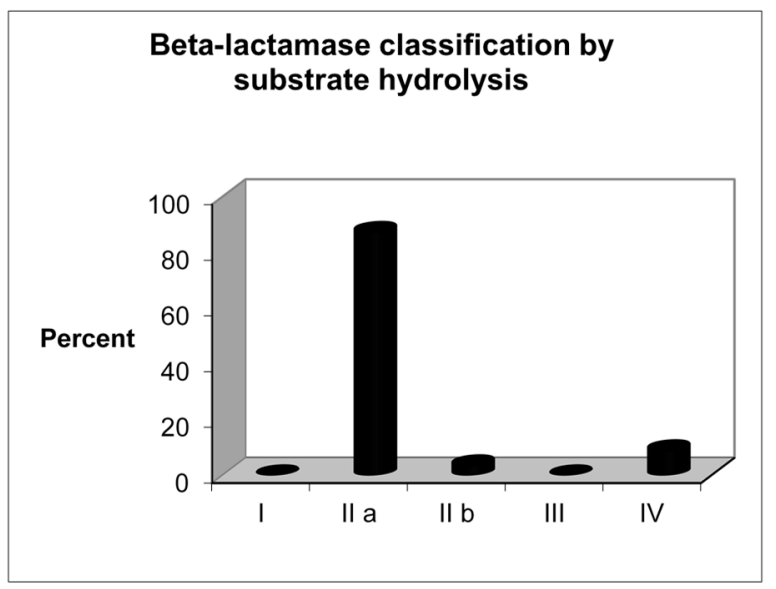

Figure 6 . The results of the classification of beta-lactamases

\subsubsection{Results of E. Test}

The results of 82 clinical cases revealed a broad spectrum beta-lactamase enzymes (ESBL) in three samples of bacteria $(17,23 a, b 29)$. As it is seen in Figure 7, clover leaf form indicates the presence of ESBL, and creating a clover leaf form in these cases because of resistant to third generation cephalosporins and enzyme containing betalactamase (ESBL) are inhibited with clavulanic acid. Lack of beta-lactamase enzyme (ESBL) is shown in figure A.

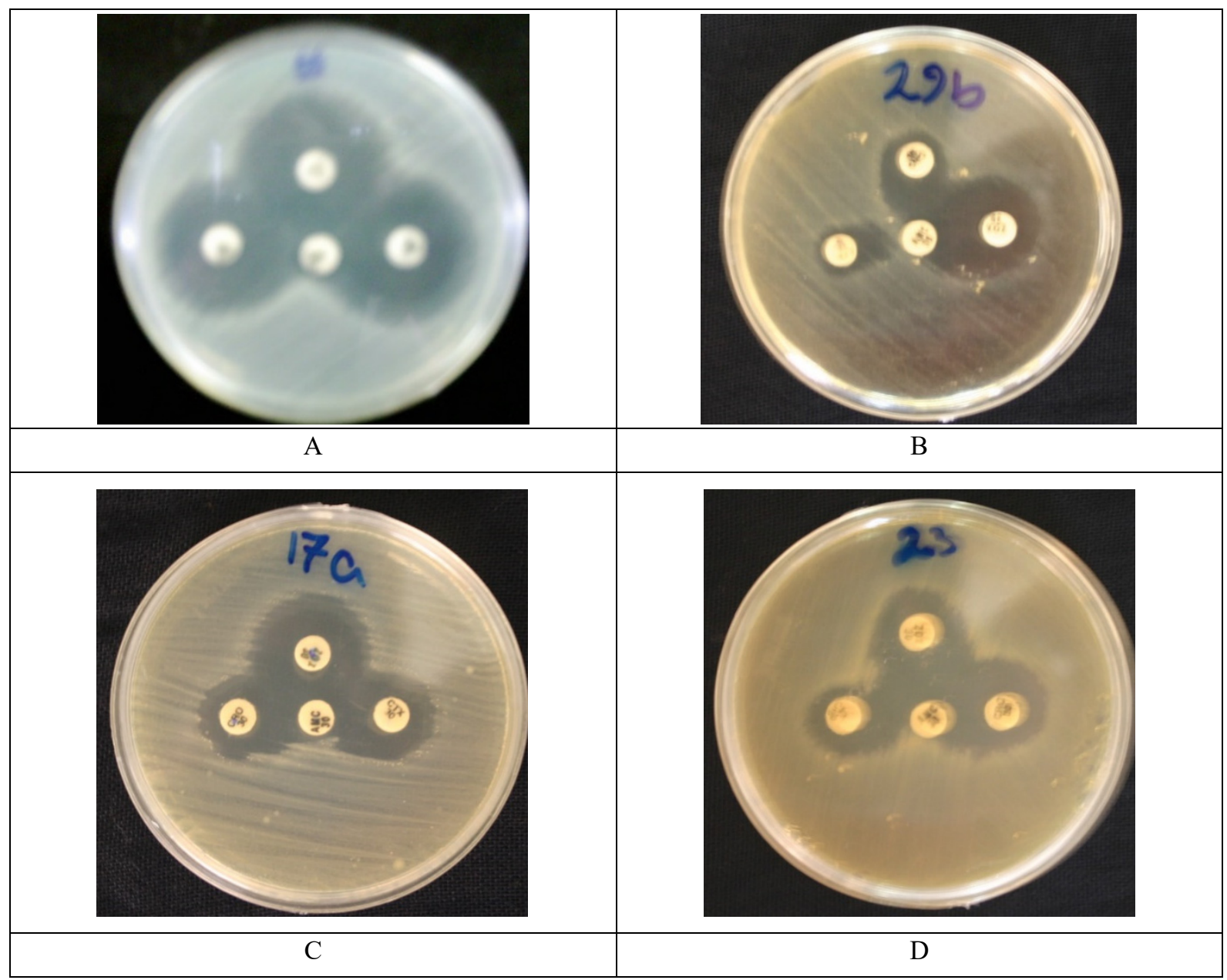

Figure 7. The results of A: ESBLS= bacterial non-ESBL, $\mathrm{C}, \mathrm{B}$ and $\mathrm{D}=$ bacteria with ESBL 


\subsection{The Plasmid DNA Extraction}

Plasmid DNA extraction on $20 \%$ of the samples (21 samples) by agarose gel $0.8 \%$ is shown in Figure 8 .

As it can be seen in the figure, plasmid samples have different bands.
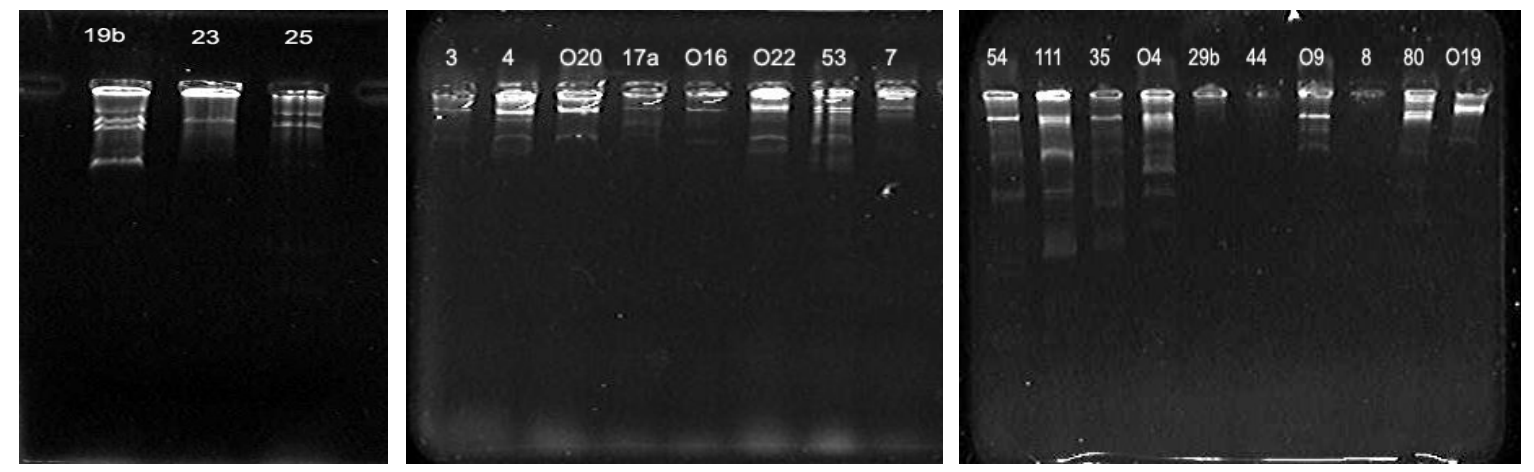

Figure 8. Results of the extraction of plasmid DNA (agarose gel $0.8 \%$ )

\section{References}

Barnaud, G., Labia, R., Raskine, L., Sanson-Le Pors, M. J., Philippon, A., \& Arlet, G. (2001). Extension of resistance to cefepime and cefpirome associated to a six amino acid deletion in the H-10 helix of the cephalosporinase of an Enterobacter cloacae clinical isolate. FEMS Microbiol. Lett, 195, 185-190.

Bradford, P.A. (2001). Extended-spectrum betalactamases in the 21st century: characterization, epidemiology, and detection of this important resistance threat. Clin. Microbiol. Rev, 14, 933-951.

Bret, L., Chanal-Claris, C., Sirot, D., Chaibi, E. B., Labia, R., \& Sirot, J. (1998). chromosomally encoded ampC type $\beta$-lactamase in a clinical isolate of Proteus mirabilis. Antimicrob. Agents Chemother, 42(5), 1110-4.

Bush, K. (1989a). Classification of $\beta$-lactamases: groups 1, 2a, 2b and 2b'. Antimirob. Agents Chemother, 33(3), 264-270.

Bush, K. (1989b). Classification of $\beta$-lactamases: groups 2c, 2d, 2e, 3 and 4. Antimirob. Agents Chemother, 33(3), 271-276.

Bush, K., \& Jacoby, G. A. (1997). Nomenclature of TEM $\beta$-lactamases. J. Antimicrob. Chemother, 39, 1-3.

Bush, K., Jacoby, G. A., \& Medeiros, A. A. (1995). A functional classification scheme for $\beta$ - lactamases and its correlation with molecular structure. Antimicrob. Agents Chemother, 39, 1211-1233.

Cudron, P. E., Moland, E. S., \& Sanders, C. C. (1997). Occurrence and detection of extended spectrum $\beta$ lactamases in members of the family Enterobacteriaceae at a veteran's medical center: seek and you may find. J. Clin. Microbiol, 35(10), 2593-2597.

Eftekhar, F., Hosseini-Mazinani, S. M., Ghandili, S., Hamraz, M., \& Zamani, S. (2005). PCR detection of plasmid mediated TEM, SHV and AmpC $\beta$-lactamases in community and nosocomial urinary isolates of Escherichia coli. Iran. J. Biotechnol, 3(1), 48-54.

Gonzalez, C. M., \& Schaeffer, A. J. (1999). Treatment of urinary tract infection: what's old, what's new and what works? World J. Urol, 17, 372-382.

Gupta, K. (2003). Addressing antibiotic resistance. Dis. Mon, 49, 99-110.

Hosseini-Mazinani, S. M., Jafar-Nejad, H., \& Ghandili, S. (2003). Beta-lactam resistance patterns of E. coli isolated from urinary tract infections at a major university hospital in Iran. J. Sci. Islam. Rep. Iran, 16, 209212.

Hosseini-Mazinani, S. M., Nakajima, E., Ihara, Y., Kameyama, K. Z., \& Sugimoto, K. (1996). Recovery of active $\beta$-lactamases from Proteus vulgaris and RTEM-1 hybrid by random mutagenesis by using dnaQ of Escherichia coli. Antimicrob. Agents Chemother, 40, 2152-2159.

Jacoby, G. A., \& Medeiros, A. A. (1991). More extended-spectrum beta-lactamases. Antimicrob. Agents Chemother, 35, 1697-1704. 
Kim, J., Kwon, Y., Pai, H., Kim, J. W., \& Cho, D. T. (1998). Survey of Klebsiella pneumoniae strains producing extended spectrum $\beta$-lactamases: prevalence of SHV-12 and SHV-2a in Korea. J. Clin. Microbiol, 36, 14461449.

Livermore, D. M. (1995). Beta-lactamases in laboratory and clinical resistance. Clin. Microbiol, Rev., 8, 557-584.

National Committee for Clinical Laboratory Standards. (2000a). Methods for dilution antimicrobial susceptibility tests for bacteria that grow aerobically, fifth edition: approved standard M7-A5. NCCLS, Wayne, Pennsylvania, USA.

National Committee for Clinical Laboratory Standards. (2000b). Performance standards for antimicrobial disc susceptibility tests, seventh edition: approved standard M2-A7. CCLS, Wayne, Pennsylvania, USA.

Pitout, J. D., Thomson, K. S., Hanson, N. D., Ehrhardt, A. F., Coudron, P., \& Sanders, C. C. (1998). Plasmidmediated resistance to expanded-spectrum cephalosporins among Enterobacter aerogenes strains. Antimicrob. Agents Chemother, 42, 596-600.

Ross, G. W., \& O’Callaghan, C. H. (1975). ß-lactamase assays. Methods Enzymol, 43, 68-85.

Sutcliffe, J. G. (1978). Nucleotide sequence of the ampicillin resistance gene of Escherichia coli plasmid pBR322. Proc. Natl. Acad. Sci. USA, 75, 3737-3741.

Winokur, P. L., Vonstein, D. L., Hoffman, L. G., Uhlenhopp, E. K., \& Doren, G. (2001). Evidence for transfer of CMY-2 AmpC $\beta$-lactamase plasmids between Escherichia coli and Salmonella isolates from food, animals and humans. Antimicrob. Agents Chemother, 45, 2716-2722.

\section{Copyrights}

Copyright for this article is retained by the author(s), with first publication rights granted to the journal.

This is an open-access article distributed under the terms and conditions of the Creative Commons Attribution license (http://creativecommons.org/licenses/by/4.0/). 